\title{
Penerapan Metode Brainstorming Berbantu Alat Peraga terhadap Kemampuan Komunikasi Matematis Peserta Didik
}

\author{
Hella Jusra $^{1 *}$, Syifa Rahmadiana ${ }^{2}$, Wahidin ${ }^{3}$ \\ Universitas Muhammadiyah Prof. Dr. HAMKA \\ "hella.jusra@uhamka.ac.id
}

Diterima: April 2020. Disetujui: Mei 2020. Dipublikasikan: Juli 2020.

\begin{abstract}
ABSTRAK
Penelitian bertujuan untuk menelaah dan menghasilkan kajian tentangimplementasi metode Brainstorming berbantu alat peraga matematika terhadap kemampuan komunikasi matematis peserta didik. Metode penelitian yang digunakan adalah quasi experimental dengansampel yang diteliti sebanyak 72 peserta didik tingkat SMP secara random. Penelitian ini terdiri dari dua kelas, yaitu kelas eksperimen dan kelas kontrol. Dalam penelitian ini teknik pengumpulan data menggunakan instrumen kemampuan komunikasi matematis berbentuk uraian. Teknik analisis data dengan menggunakan uji-t setelah dilakukan uji prasyarat. Berdasarkan hasil penelitian didapatkan rata-rata kemampuan komunikasi matematis peserta didik yang diajar menggunakan metode Brainstorming berbantu alat peraga lebih tinggi dibandingkan dengan yang tidak diajar menggunakan metode Brainstorming berbantu alat peraga. Hal ini dapat disimpulkan bahwa metode pembelajaran Brainstormingberbantu alat peraga dapat meningkatkan kemampuan komunikasi matematis peserta didik dengan kriteria sedang.

Kata kunci:metode Brainstorming, alat peraga, kemampuan komunikasi matematis.
\end{abstract}

\begin{abstract}
Thestudy aims to determine whether or not there is an implementation of theBrainstorming method assisted aid teaching to the students'mathematical communication ability. Thesample of this research are 72 students. The research used data collection method by using instrument test of mathematical communication ability in the form ofdescription. Data analysis techniques using t-test after the prerequisite test. Based on the results of the study it was found that the average of mathematical communication ability of students taught using the Brainstorming methodassisted props were higher than those not taught using the Brainstorming methodassisted props. It can be concluded that theBrainstorming method assisted props can improve mathematical communication ability of students with medium criteria.
\end{abstract}

Keywords: Brainstorming method, aid teaching, mathematics communication ability.

How to Cite:Jusra, Hella. (2020). Penerapan Metode Brainstorming Berbatu Alat Peraga terhadap Kemampuan Komunikasi Matematis Peserta Didik. Journal of Medives: Journal of Mathematics Education IKIP Veteran Semarang, 4(2), 263-273. 


\section{PENDAHULUAN}

Matematika merupakan salah satu ilmu yang mendasari perkembangan teknologi modern, yang mempunyai peranan penting dalam berbagai disiplin ilmu dan memajukan daya pikir manusia. Di dunia ini peserta didik tidak dapat terlepas dari aktivitas yang namanya matematika, karena matematika dapat menyelesaikan masalah dalam kehidupan seharihari(Sari et al., 2014). Pada kenyataannya peserta didik menganggap matematika pembelajaran yang rumit dengan menggunakan banyak angka serta rumus-rumus yang menurut peserta didik itu sukar.ada umumnya matemati-ka merupakan pelajaran penting yang perlu dikuasai, sehingga peserta didik diharapkan mampu mempunyai pemikir-an yang kritis, sistematis, kreatif, dan logis. Pada kenyataannya peserta didik menganggap matematika pembelajaran yang rumit dengan menggunakan banyak angka serta rumus-rumus yang menurut peserta didik itu sukar.

Pembelajaran

matematika seharus-nya tidak hanya menekankan pada pemahaman konsep tetapi juga melatih peserta didik mengungkapkan pendapat-nya dalam proses menyelesaikan sebuah masalah. Pembelajaran matematika tidak hanya sebatas memahami materi dan mengerjakan soal yang dipelajari, namun ada beberapa kemampuan yang perlu dimiliki peserta didik dalam pembelajaran matematika. Berbagai kemampuan yang diharapkan dapat dikuasai dari setiap kegiatan pembelajaran matematika. Kemampuan matematis yang harus dicapai dan dikuasi peserta didik diantaranya kemampuan pemahaman, penalaran, pemecahan masalah, komuni-kasi, koneksi, representasi, dan masih banyak lagi.Salah satunya kemampuan dalam mengkomunikasikan suatu masalah ke berbagai bentuk yang berbeda. Kemampuan seperti itu disebut kemampuan komunikasi matematis.

Menurut Permendiknas nomor 22 tahun 2006 tentang standar isi untuk satuan pendidikan dasar dan menengah secara umum menjelaskan bahwa mata pelajaran matematika bertujuan agar peserta didik memiliki kemampuan sebagai berikut. (1) Memahami konsep matematika, menjelaskan keterkaitan antarkonsep dan mengaplikasikan konsep atau algoritma, secara luwes, akurat, efisien, dan tepat, dalam pemecahan masalah; (2) menggunakan penalaran pada pola dan sifat, melakukan manipulasi matematika dalam membuat generalisasi, menyusun bukti, atau menjelaskan gagasan dan pernyataan matematika; (3) memecahkan masalah yang meliputi kemampuan memahami masalah, merancang model matematika, menyelesaikan model dan menafsirkan solusi yang diperoleh; (4) mengkomunikasikan gagasan dengan simbol, tabel, diagram, atau media lain untuk memperjelas keadaan atau masalah; (5) memiliki sikap menghargai kegunaan matematika dalam kehidupan, yaitu memiliki rasa ingin tahu, perhatian, dan minat dalam mempelajari matematika, serta sikap ulet dan percaya diri dalam pemecahan masalah (Afandi, 2013).

Tujuan permendiknas sejalan dengan tujuan umum pembelajaran 
matematika yang dirumuskan oleh National Council of Teacher of Mathematics (NCTM) yang menetapkan lima standar kemampuan matematis yang harus dimiliki oleh peserta didik, yakni kemampuan pemecahan masalah (problem solving), penalaran dan bukti (reason and proof), komunikasi (communication), koneksi (connections), dan kemampuan representasi (representation)(Hodiyanto, 2017). Lima kemampuan matematis yang harus dimiliki peserta didik tersebut sama pentingnya untuk dikembangkan. Akan tetapi belum banyak yang menekankan kemampuan komunikasi peserta didik.

Kemampuan komunikasi matematis merupakan kecakapanseseorang dalam menghubungkan pesan-pesan dengan membaca, mendengarkan, bertanya, danmengkomunikasikan letak masalah serta mempresentasikannyadalampemecahan masalah yang terjadi dalam suatu lingkungankelas, dimanaterjadipengaliha npesanyangberisisebagian materi matematika yang dipelajari(Asikin \& Iwan Junaedi, 2013). Menurut Hodiyanto kemampuan komunikasi matematis peserta didik dalam menyampaikan ide matematika baik secara lisan maupun tulisan (Hodiyanto, 2017).

Sumarmo mengungkapkan indikator yang berbeda untuk menunjukkan kemampuan komunikasi matematika meliputi kemampuan: (1) menyatakan situasi, gambar, diagram atau benda nyata kedalam bahasa, simbol, ide atau model matematik; (2) menjelaskan ide, situasi dan relasi metematika secara lisan atau tulisan; (3) mendengarkan, berdis-kusi dan menulis tentang matematika; (4) membaca dengan pemahaman suatu representasi matematika tertulis; serta (5) mengungkapkan kembali suatu uraian atau paragraf matematika dalam bahasa sendiri. Kemampuan tersebut dapat tergolong pada kemampuan berpikir matematik rendah atau tingkat tinggi bergantung padakomunikasi yang terlibat (Darkasyi et al., 2014).

Kemampuan komunikasi matematis peserta didik sangatlah penting dalam pembelajaran matematika, namun pada kenyataannya kemampuan komunikasi matematis peserta didik tergolong masih rendah. Kegiatan pembelajaran di sekolah umumnya masih menggunakan pembelajaran yangkomunikasinya hanya terjadi dari guru ke peserta didik. Hal ini menyebabkan peserta didik kurang mampu untuk mengekpresikan ide pengetahuan yang dimiliki oleh masingmasing peserta didik. Keterlibat-an peserta didik dalam kegiatan pembelajaran menjadi tidak optimal karena metode pembelajaran yang kurang menarik sehingga mengakibatkan peserta didik menjadi lebih individualis karena kurangnya interaksi antar peserta didik dalam berbagi ide.

Berdasarkan hasil observasi di SMA Negeri 5 Magelang tentang kemampuan komunikasi menunjukkan bahwa perlu ditingkatkan kemampuan komunikasi interpersonal peserta didik (Lianasari dan Purwanto, 2016). Di sinilah perlunya guru untuk menggunakan metode pengajaran baru seperti metode Brainstorming untuk mengem- 
bangkan kemampuan komunikasi matematis peserta didik karena saat ini peran guru adalah sebagai fasilitator. Penjelasan tersebut menggambarkan bahwa rendahnya kemampuan komunikasi matematis peserta didik, oleh karena itu dibutuhkan metode pembelajaran yang membuat peserta didik bebas mengeluarkan ide atau pendapat dalam pembelajaran untuk meningkatkan komunikasi matematis peserta didik. Metode pembelajaran yang tepat yaitu metode pembelajaran Brainstorming.

Brainstorming merupakan alternatif yang tepat karena metode Brainstorming berorientasi pada kemampuan peserta didik untuk mengemukakan ide sebanyak mungkin dalam pemecahan suatu persoalan, mampu menyampaikan pendapat dan mengaktualisasikan diri dalam memecahkan suatu masalah serta mampu menghargai pendapat orang lain(Widowati, 2003).Selanjutnya, Alblwi mengatakan bahwa Brainstorming adalah konferensi inovatif dengan sifat khusus untuk menghasilkan daftar ide yang dapat digunakan sebagai petunjuk untuk mengarahkan siswa pada pengembangan suatu masalah dengan memberikan kesempatan kepada tiap siswa untuk mengekspresikan ideidenya dan membagikan ide-ide tersebut dengan orang lain, serta mendorong ideide baru (Al-khatib, 2012). Teori yang dikemukakan tersebut dengan pengimplementasian pembelajaran metode Brainstorming dapat mengembangkan gagasan yang dimiliki peserta didik pada suatu permasalahan yang dihadapi. Adapunlangkah-langkah dalam pembelajaran yang menggunakan metode brainstormingadalah: (1)pemberian informasi dan motivasi, (2) identifikasi,(3) klasifikasi, (4) verifikasi dan(5) konklusi (penyepakatan).(Isman dalam Dharayanti et al., 2013).

Metode pembelajaran Brainstormingmemiliki kelebihan, yaitu (1) anakanak aktif berpikir untuk menyatakan pendapat, (2) melatih siswa berpikir dengan cepat dan tersusun logis, (3) merangsang siswa untuk selalu siap berpendapat yang berhubungan dengan masalah yang diberikan oleh guru, (4) meningkatkan partisipasi siswa dalam menerima pelajaran dan (5) siswa yang kurang aktif mendapatkan bantuan dari temannya yang pandai atau dari guru Adapun kekurangan metode Brainstorming yaitu: (1) memerlukan waktu yang cukup lama dalam pelaksanaanya, (2) lebih didominasi oleh siswa pandai dan aktif sementara siswa yang kurang pandai dan kurang aktif akan tertinggal, dan (3) guru tidak merumuskan suatu kesimpulan karena siswalah yang bertugas untuk merumuskan kesimpulan (N.K, 2012).

Pada penelitian sebelumnya belum ada yang menggunakan metode Brain-storming dengan menerapkan alat peraga pada proses pembelajaran, sehingga pada penelitian ini diterapkan metode pembelajaran Brainstorming dengan berbantu alat peraga yang diharapkan dapat membuat peserta didik menjadi lebih aktif dalam mengemukakan pendapatnya. Kemudiandapat membuat peserta didik tertarik karena alat peraga yang dibuat berdasarkandari benda konkrit.Alat 
peraga diterapkan dalam pembelajaran dengan metode brain-storming agar peserta didik dapat lebih mengeksplor pengetahuannya, sehingga ilmunya dapat berkembang. Selain itu, permasalahan-permasalahan yang diberikan juga suatu persoalan yang terkait dengan kehidupan sehari-harinya, sehingga peserta didik dapat membayangkan permasalahan dan solusinya. Menurut Prastowo alat peraga adalah sebagai media yang menggambarkan atau mengilustrasikan konsep atau materi yang diajarkan. Alat peraga akan memudahkan anak untuk belajar karena dapat mengilustrasikan materi secara nyata(Aprinastuti et al., 2017). Dengan alat peraga, siswa dapat langsung melihat bendanya dan mengadakan percobaan-percobaan secara langsung. Ide yang muncul dari peserta didik dapat langsung dicoba dengan alat peraga, sehingga mereka dapat mempelajari bahwa cara penemuan solusinya sudah benar dan tepat. Peranan alat peraga dalam pembelajaran matematika sangat penting karena alat peraga disamping membantu guru untuk menjelaskan konsep-konsep yang sedang dipelajari dapat juga membantu siswa untuk bertanya dan mengemukakan pendapatnya tentang konsep yang diketahui melalui alat peraga.

Penelitian ini bertujuan untuk menelaah dan menghasilkan kajian tentang kemampuan komunikasi matematis peserta didik terhadap penerapan metode pembelajaran Brainstorming berbantu alat peraga. Penelitian ini bermanfaat sebagai bahan acuan untuk melakukan penelitian lanjutan yang yang relevan.

\section{METODEPENELITIAN}

Penelitian ini menggunakan metode quasi experimental karena tidak mengacak subyek dan membentuk kelas baru, melainkan subyek yang ada dalam kelas tersebut. Pada penelitian ini, peneliti melakukan perlakuan terhadap kelompok eksperimen untuk mengetahui kemampuan komunikasi matematis peserta didik dengan kelompok kontrol yang tidak mendapat perlakuan. Pada akhir pembelajaran kedua kelompok kelas diberikan tes yang sama, kemudian dibandingkan kemampuan komunikasi matematis peserta didik dari dua kelompok tersebut.

Populasi pada penelitian ini adalah seluruh siswa SMPN kelas VII dengan sampel yang dipilih adalah 2 (dua) kelas dengan teknik cluster random sampling.

Data kemampuan komunikasi matematis peserta didik dengan metode pembelajaran Brainstormingberbantu alat peraga diperoleh dari hasil tes bentuk uraian dengan pokok bahasan segiempat dan segitiga yang diujikan kepada kedua kelompok. Uji statistik yang digunakan dengan pengujian hipotesis dengan taraf signifikan $(\alpha=0,05)$.

Terdapat pedoman penskoran untuk tes kemampuan komunikasi matematis dengan penjelasan sebagai berikut. (1) Skor 0: tidak ada respon, komunikasi tidak efisien, misinterpretasi; (2) skor 1: respon kurang lengkap dan kurang jelas, ragu-ragu, diagram 
kurang lengkap, komunikasi kurang efisien, sajian kurang logis, ada gap cukup besar; (3) skor 2: respon hampir lengkap/jelas, namun ragu-ragu, diagram kurang lengkap, komunikasi tidak efisien, sajian kurang logis, ada gap cukup serius; (4) skor 3: respon hamper lengkap dan jelas, tidak raguragu, diagram hampir lengkap, komunikasi efisien, sajian logis, dan gap kecil; dan (5) skor 4: respon lengkap dan jelas, tidak ragu-ragu, diagram lengkap, komunikasi efisien, sajian logis, disertai dengan contoh (Hendriana \& Soemarmo, 2014).

\section{HASIL DAN PEMBAHASAN}

Penelitian yang dilakukan pada duakelas dengan kelas eksperimen adalah kelas yang diterapkan pembelajaran metode Brainstormingdengan alat peraga, sedangkan kelas kontrol adalah kelas yang tidak diterapkan metode Brainstorming dengan alat peraga untuk mengukur kemampuan komunikasi matematis peserta didik pada materi segitiga dan segiempat. Untuk melihat hasil dari pengimplementasian dari metode Brainstorming dengan alat peraga efektif adalah dengan melakukan pengujian statistik.Hasil penelitian yang didapat dengan uji statistik sebagai berikut.

\section{Uji Normalitas}

Pengujian normalitas dilakukan dengan menggunakan uji Lilliefors. Berdasarkan analisis perhitungan distribusi normal kelas eksperimen pada taraf signifikan $\alpha=0,05$ dan $\mathrm{n}=36$ maka diperoleh hasil $L_{\text {hitung }}$ sebesar 0,1407 dan $L_{\text {tabel }}$ sebesar $\quad 0,1476$. Karena
$L_{\text {hitung }}=0,1407<0,1478=L_{\text {tabel }}$, maka dapat disimpulkan bahwa data tersebut berdistribusi normal.

Berdasarkan analisis perhitungan distribusi normal kelompok kontrol pada taraf signifikan 0,05 dann $=36$ maka diperoleh hasil $L_{\text {hitung }}$ sebesar 0,1443 dan $L_{\text {tabel }}$ sebesar 0,1476 karena $L_{\text {hitung }}=0,1443<0,1476=L_{\text {tabel }}$, maka dapat disimpulkan bahwa data tersebut berdistribusi normal. Berdasarkan perhitungandidapat bahwa data dari kelompok eksperimen dan kelompok kontrol berdistribusi normal.

\section{Uji Homogenitas}

Uji homogenitas dua kelas antara kelas kontrol dan kelas eksperimen dilakukan dengan menggunakan uji Fisher. Berdasarkan hasil perhitungan didapat $F_{\text {hitung }}$ sebesar1,264. Pada taraf signifikan sebesar 0,05 dengan $d k$ pembilang 36 dan $d k$ penyebut 36 menggunakan metode interpolasi diperoleh $F_{\text {tabel }}$ sebesar 1,7459.

Berdasarkan data yang diperoleh dapat dilihat bahwa $F_{\text {hitung }}=1,264<$ $1,7459=F_{\text {tabel }}$ maka $\quad H_{0}$ diterima, dengan demikian dapat disimpulkan bahwa kedua kelas tersebut homogen.

Berdasarkan hasil pengujian persyaratan analisis yang meliputi uji normalitas dan uji homogenitas maka diketahui bahwa kedua kelas berada pada distribusi normal dan dalam kondisi yang homogen.

\section{Uji Hipotesis}

Berdasarkan hasil data prasyarat pengujian hipotesis didapatkan data berdistribusi normal dan homogen, 
sehingga pengujian hipotesis yang digunakan adalah uji- $t$ dan menghasilkan ditolaknya $H_{0}$ yang berarti terdapatmetode Brainstormingberbantu alat peraga terhadap kemampuan komunika-si matematis peserta didik.

\section{Pembahasan}

Penerapan pembelajaran Brainstormingberbantu alat peragapada kelompok eksperimen disebabkan oleh besarnyanilai rata-rata tes kemampuan komunikasi matematis dengan kelompok kontrol.hasil rata-rata kemampuan komunikasi matematis peserta didik yang diperoleh pada peserta didik kelompok eksperimen lebih tinggi dibandingkan dengan peserta didik kelompok kontrol. Pada pengujian normalitas, terlihat bahwa kedua kelas berdistribusi normal.

Kegiatan belajar dengan menggunakan metode Brainstormingadalah kegiatan belajar dimana peserta didik dibentuk kelompok heterogen 6 orang dengan setiap kelompok diberi kesempatan untuk pernyataan sebanyak mungkin tanpa adanya batasan dengan berbantu alat peraga yang diterima dan LKPD untuk menemukan konsep materi yang akan dipelajari. Pelajaran dikatakan berhasil apabila semua anggota dalam kelompok sudah menguasai materi yang diberikan.

Kegiatan belajar dengan menggunakan metode Brainstormingadalah kegiatan belajar dimana peserta didik dibentuk kelompok heterogen 6 orang dengan setiap kelompok diberi kesempatan untuk pernyataan sebanyak mungkin tanpa adanya batasan dengan berbantu alat peraga yang diterima dan
LKPD untuk menemukan konsep materi yang akan dipelajari. Pelajaran dikatakan berhasil apabila semua anggota dalam kelompok sudah menguasai materi yang diberikan.

Proses belajar yang diterapkan, yaitu metode pembelajaranBrainstormingberbantu alat peraga. Kegiatan metode

pembelajaranBrainstormingterdiri dari: (1) guru memberikan materi secara singkat menjelang pemberian tugas kelompok; (2) guru membentuk kelompok yang terdiri dari 6 peserta didik; (3) guru memberikan alat peraga sederhana dan LKPD kepada setiap kelompok: (4) peserta didik dipersilakan untuk memberikan pernyataan yang kemudian dituliskan di papan tulis; (5) guru dan peserta didik mengklasifikasi pernyataan yang sesuai dengan konsep materi yang dipelajari, dan (6) peserta didik dan guru bersamasama membuat kesimpulan dari suatu permasalahan (Benanza, Pitoewas dan Yarza, 2014).

Tahap pertama yaitu pemberian informasi, peneliti mengawali pembelajaran dengan salam pembuka, kemudian mengecek kehadiran peserta didik, menyampaikan tujuan pembelajaran, menginformasikan cara belajar yang akan ditempuh. Tahap selanjutnya selanjutnya peserta didik dikelompokkan heterogen 6 peserta didik setiap kelompok yang dipilih berdasarkan ukuran lidi yang dipilih oleh peserta didik. Hal ini diharapkan agar komunikasi setiap peserta didik berjalan dengan baik tanpa perlu memilih teman dekatnya saja. Terdapat beberapa hal yang harus diperhatikan dalam 
pembelajaran

kelompok.

Pertama,peserta didik harus mengerti bahwa mereka dalam keadaan berkelompok. Kedua,peserta didik harus memahami bahwa berhasil atau tidaknya kelompok tergantung pada hasil belajar mereka. Ketiga, diperlukan saling komunikasi dengan kelompok untuk mendiskusikan sub-materi yang diberikan agar men-capai hasil yang maksimal.

Pada saat penelitian di kelompok eksperimen ditemukan beberapa karakter peserta didik yang unik. Terdapat peserta didik yang tidak saling berkomu-nikasi dengan anggota kelompoknya dan hanya mengerjakan tugasnya masing-masing dan tidak berbagi pemikirannya kepada teman sekelompoknya. Faktor lain dikarenakan kelompok yang dibentuk tidak sesuai dengan keinginan masingmasing peserta didik. Peserta didik pada tahap awal pertemuanbelum terbiasa dengan metode Brainstorming yang diberikan, sehingga masih banyak peserta didik yang memberikan pertanyaan bukan ide dari hasil pemikiran mereka.

Setelah berjalannya beberapa kali pertemuan dengan metode pembelajaran Brainstorming, siswa mulai dapat mengungkapkan hasil pemikirannya dengan bantuan alat peraga sederhana.
Antar siswa dalam kelompok berdiskusi secara bersama-sama untuk memecahkan permasalahan yang diberikan. Sebelum memecahkan masalah tersebut, peserta didik memahami materi dengan menggunakan alat peraga yang telah disediakan. Di sinilah terjadinya komunikasi antar peserta didik dengan memberikan penjelasan terhadap langkahlangkah yang dipilih dalam menyelesaikan masalah. Sesuai dengan pernyataan Osborn bahwa Brainstorming dapat membantu peserta didik mentransfer ide-ide mereka dari otak ke mulut atau ke angka-angka yang berkaitan dengan keterampilan khusus untuk menulis (Nugraha \& Indihadi, 2019).

Hasil jawaban peserta didik dalam mengukur kemampuan komunikasi matematis peserta didik dapat dilihat pada Gambar 1.Jawaban peserta didik kelas eksperimensesuai dengan salah satu indikator kemampuan komunikasi matematis peserta didik menurut Sumarmo yaitu menyatakan situasi, gambar, diaram atau benda nyata kedalam bahasa, simbol, ide atau model matematik (Darkasyi, Johar dan Ahmad, 2014). Peserta didik menjawab soal yang menghubungkan gambar ke dalam ide matematika dengan memberikan penjelasan terhadap langkah-langkah penyelesaian masalah. Penyelesaian masalah yang diberikan peserta diidk

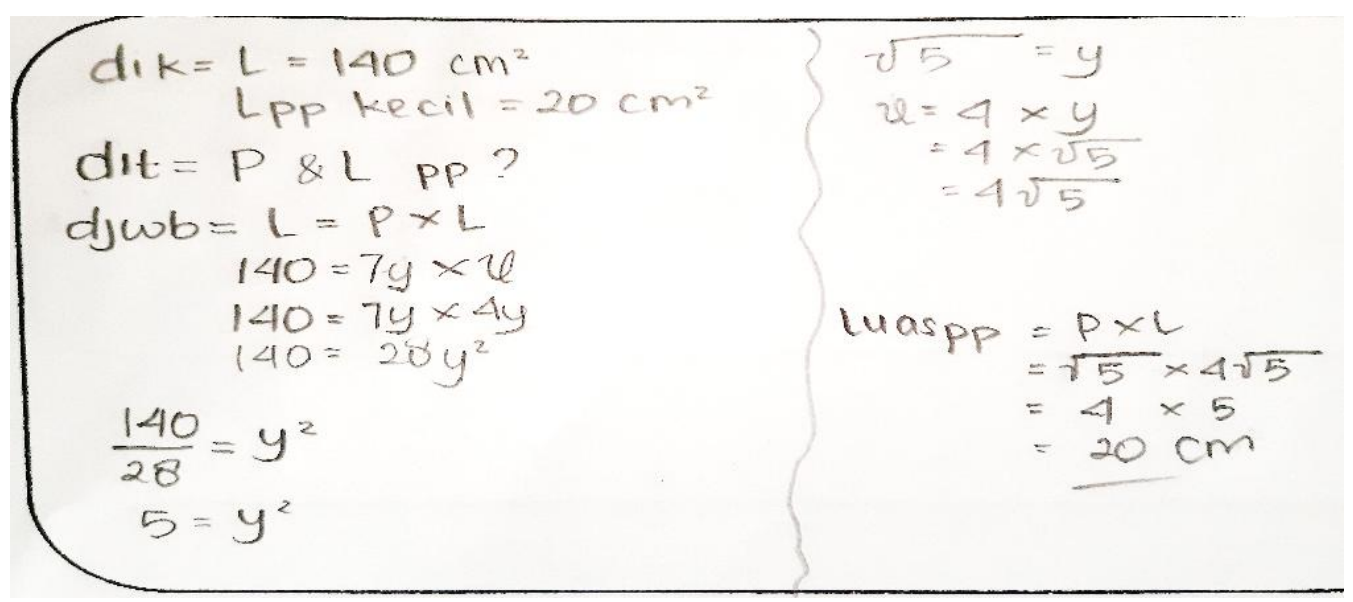


tersebut sangat sesuai dengan indikator kemampuan komunikasi matematis peserta didik pada soal nomor 1 yaitu peserta didik mampu menganalisis, memberikan penjelasan dan menyelesaikan soal. Hal ini pun membuktikan bahwa peserta didik tersebut telah mencapai indikator tersebut, sedangkan jawaban peserta didik kelas kontrol tersebut benar dalam memberikan pendapat, tetapi peserta didik belum memberikan penjelasan dengan lengkap. Hal tersebut menunjukkan bahwa kurangnya komunikasi matematis peserta didik dalam menyelesaikan suatu permasalahan. Berdasarkan analisis soal pada nomor 1 bahwa jawaban tersebut cukup sistematis, namun belum terjawab dengan tepat.

Dari hasil jawaban peserta didik terkait pengukuran kemampuan komuni-kasi matematis peserta didik mampu menjelaskan ide terhadap masalah yang diberikan, namun ada juga yang terdapat jawaban yang tidak tepat serta sistematis.

Metode Brainstorming merupakan metode yang efektif untuk memunculkan berbagai ide tentang suatu masalah dalam waktu yang terbatas melalui peran serta partisipan secara spontan. Pada penelitian ini penerapan metode Brainstorming dengan alat peraga dilakukan secara berkelompok agar terjadinya pertukaran ide dan adanya komunikasi antar peserta didik. Hal ini sejalan dengan dengan pernyataan Triansa, dkk bahwa jika peserta terdiri lebih dari sepuluh, maka akan lebih baik jika Brainstorming dilakukan secara berkelompok (Triansa et al., 2017).

$$
\text { Brainstorming dimaksudkan }
$$

untuk menstimulasi atau merangsang otak agar memikirkan masalah dengan cara baru. Ini mendorong peserta didik untuk menangkap pemikiran konvensional, logis, dan mencakup spontanitas, orisinalitas, dan imajinasi(Filgona, 2016). Tidak adanya kritik terhadap ide yang dipaparkan oleh peserta didik menjadi suatu hal yang perlu diperhatikan dalam penerapan metode ini. Adapun penggunaan alat peraga untuk mendukung keaslian dan imajinasi peserta didik dalam menyelesaikan permasalahan yang diberikan. Peserta didik dapat mengemukakan pendapatnya mengenai suatu masalah tanpa adanya penilaian dari peserta lain, sehingga ini yang dianggap adanya kemampuan komunikasi matematis peserta didik setelah diterapkan metode Brainstorming dengan bantuan alat peraga. Kemampuan peserta didik untuk berkomunikasi dalam matematika

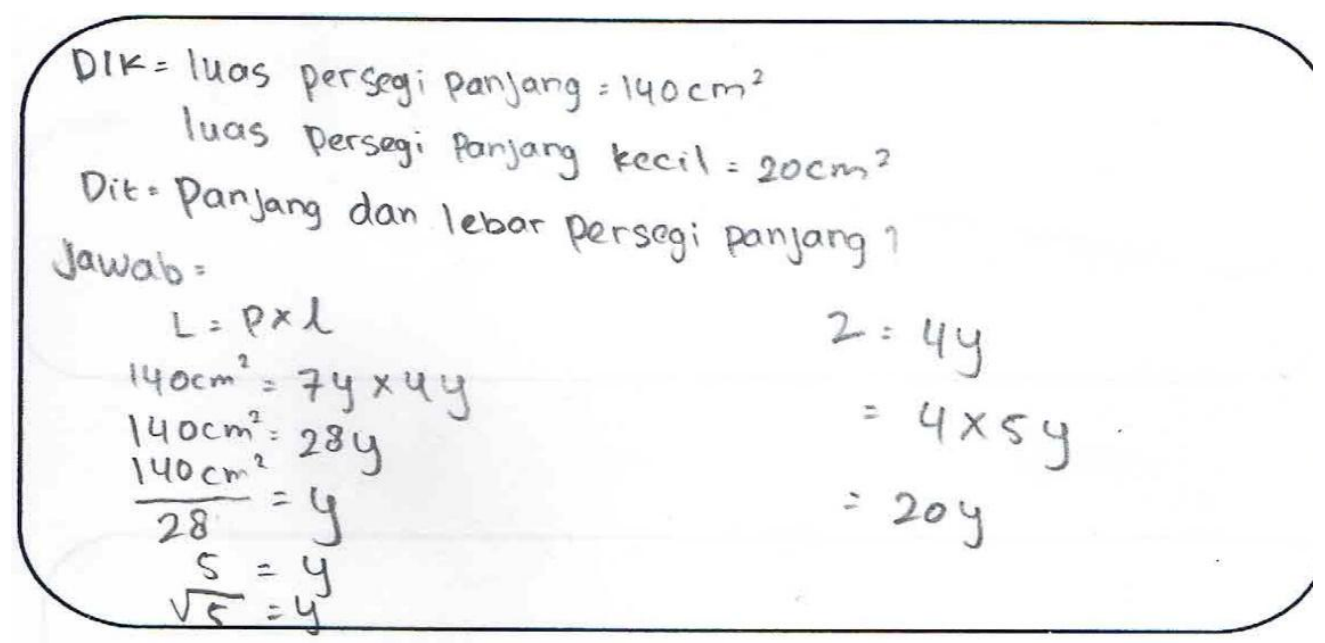

Gambar 2. Hasil Jawaban Pengerjaan Peserta Didik Kelas Kontrol 
secara lisan maupun tulisan dalam mengekspresikan ide-ide matematika misalnya berupa konsep, rumus, atau strategi pe-nyelesaian masalah dalam matematika.

$\begin{array}{lrr}\text { Hasil penelitian menunjukkan } \\ \text { bahwa } & \text { rata-rata kemampuan }\end{array}$
komunikasi matematis peserta didik lebih tinggi ketika diterapkan metode pembelajaran Brainstorming dengan alat peraga dibandingkan dengan yang tidak diterapkan metode Brainstormingberbantu alat peraga.

\section{PENUTUP}

Pembelajaran menggunakan metode Brainstorming dinilai efektif untuk meningkatkan kemampuan komunikasi matematis peserta didik. Peserta didik menjadi lebih aktif dalam proses pembelajaran. Metode pembelajaran ini juga membantu siswa menemukan dan memahami lebih dalam mengenai konsep materinya dan dapat memecahkan masalah-masalah yang terjadi dalam kehidupan sehari-hari.

Berdasarkan hasil penelitian dan pembahasan bahwa kemampuan komunikasi matematis peserta didik yang diajarkan dengan menggunakan metode Brainstorming berbantu alat peraga lebih tinggi daripada kemampuan komunikasi matematis peserta didik yang tidak diajarkan dengan menggunakan metode pembelajaran Brainstormingberbantu alat peraga. Dengan demikian, terdapat pengaruh metode pembelajaran Brainstorming terhadap komunikasi matematis peserta didik.

\section{DAFTAR PUSTAKA}

Afandi, A. (2013). Pendekatan Openended dan Inkuiri Terbimbing ditinjau dari Kemampuan Pemecahan Masalah dan Representasi Multipel Matematis. Junal Pendidikan Matematika, 8(1), 1-11.

Al-khatib, B. A. (2012). The Effect of Using Brainstorming Strategy in Developing Creative Problem Solving Skills among Female Students in Princess Alia University College Department of Psychology and Special Education. American International Journal of Contemporary Research, 2(10), 29-38.

Aprinastuti, C., Erlita, B., \& Anggadewi, T. (2017). Pengembangan Alat Peraga untuk Meningkatkan Kemampuan Belajar Matematika pada Anak dengan ADHD. 1, 240-250.

Asikin, M., \& Iwan Junaedi. (2013). Unnes Journal of Mathematics Education Research. Jounal of Mathematics Education Research, 2(1).

Darkasyi, M., Johar, R., \& Ahmad, A. (2014). Peningkatan Kemampuan Komunikasi Matematis dan Motivasi Siswa dengan Pembelajaran Pendekatan Quantum Learning pada Siswa SMP Negeri 5 Lhokseumawe. Jurnal Didaktik Matematika, 1(1), 21-34.

Dharayanti, Y. P., Sumantri, M., \& Widiana, I. (2013). Pengaruh Model Pembelajaran Learning Cycle 5E Berbasis Brainstorming Terhadap Kemampuan Berpikir. Mimbar PGSD Undiksha, 1(1).

Filgona, J. (2016). Effect of Brainstorming Learning Strategy 
on Junior Secondary School Students' Academic Achievement in Social Studies in Yola Educational Zone, Adamawa State, Nigeria. International Journal of Progressive Sciences and Technologies, 3(2), 108-115.

Hendriana, H., \& Soemarmo. (2014). Penilaian Pembelajaran Matematika. PT. Reefika Aditama.

Hodiyanto. (2017). Kemampuan Komunikasi Matematis dalam Pembelajaran Matematika. Admathedu, 7(1), 9-18.

N.K, R. (2012). Strategi Belajar Mengajar. PT. Bineka Citra.

Nugraha, D., \& Indihadi, D. (2019). Brainstorming in Scientific Writing in Elementary School. Journal of Physics: Conference Series, $1318(1)$. https://doi.org/10.1088/1742-
6596/1318/1/012026

Sari, P., Bennu, S., \& Mallo, B. (2014). Siswa Kelas VIII Pada Materi Luas Permukaan dan Volume Limas Di Smp Negeri 19 Palu. 3(2).

Triansa, E. A., Zendrato, J., \& Appulembang, O. D. (2017). The Effect of Brainstorming Implementation on Students' Engagement in Learning about Probability in Math Classes in Grade XI IPA at SMA ABC Cikarang. Polyglot: Jurnal Ilmiah, 12(1), 20. https://doi.org/10.19166/pji.v1i1.3 80

Widowati, A. (2003). Brainstorming Sebagai Alternatif Pengembangan Berfikir Kreatif dalam Pembelajaran Sains Biologi. 